\author{
dr Jacek SIERAK \\ Wydział Ekonomii i Zarządzania, Uczelnia Lazarskiego \\ e-mail: jacek.sierak@lazarski.pl \\ ORCID: 0000-0001-8968-133X
}

DOI: $10.15290 /$ oes.2018.03.93.16

\title{
ALOKACJA FUNDUSZY UNIJNYCH A WYDATKI INWESTYCYJNE GMIN
}

\section{Streszczenie}

Artykuł ma na celu wykazanie, jaki jest wpływ pozyskiwania funduszy unijnych na aktywność inwestycyjna gmin. W wielu z nich niedorozwój podstawowej infrastruktury technicznej nadal stanowi zasadniczą barierę rozwojową i dlatego wymaga dalszych nakładów finansowych. Dla wielu samorządów pozyskanie dotacji unijnych jest szansą na przyspieszenie procesów rozwoju i niwelowania ilościowej i jakościowej luki infrastrukturalnej.

Słowa kluczowe: wydatki inwestycyjne gmin, fundusze Unii Europejskiej, finansowanie infrastruktury komunalnej

\section{ALLOCATION OF EU FUNDS AND INVESTMENT EXPENDITURE OF COMMUNITIES AND POVIAT CITIES}

The aim of the article is to demonstrate the impact of obtaining EU funds on the intensity of investment projects of communes and poviat cities. The underdevelopment of the basic technical infrastructure in many of them is still a major barrier to development and, therefore, requires further financial outlays. For many local governments, obtaining EU subsidies is an opportunity to accelerate the development processes and to eliminate the quantitative and qualitative infrastructure gap.

Keywords: investment of municipalities, European Union funds, financing of municipal infrastructure

JEL classification: $\mathrm{H} 70, \mathrm{H} 71, \mathrm{H} 72$

\section{Wstęp}

Wraz z przystapieniem Polski do Unii Europejskiej zaistniały nowe możliwości finansowania inwestycji w sektorze publicznym. W odniesieniu do nowych państw członkowskich, charakteryzujących się stosunkowo niskim poziomem rozwoju, finansowanie inwestycji może być w części realizowane w ramach środków budżetowych UE. Dla wielu samorządów pozyskanie dotacji unijnych jest szansą na przy- 
spieszenie procesów rozwoju i niwelowanie występującej na ich terenie ilościowej i jakościowej luki infrastrukturalnej.

Celem artykułu jest wykazanie wpływu funduszy unijnych na aktywność inwestycyjna gmin, a także zbadanie jak silna jest współzależność tych dwóch zmiennych. W części analitycznej zostanie omówionych kilka istotnych zagadnien, w tym: rozkład alokacji środków unijnych w polskich gminach oraz wykazanie, jak znaczący jest ich wpływ na wielkość inwestycji. Wyniki badań bazuja na analizie statystyki GUS i Ministerstwa Finansów, a także wynikach autorskich badań ankietowych, zrealizowanych w 2018 r. na próbie około 1300 jednostek samorządu terytorialnego szczebla podstawowego. Mają one zobrazować tendencje występujące w skali kraju, a także zidentyfikować różnice w poszczególnych województwach. Z powodu ograniczonej objętości publikacji w treści artykułu skupiono się przede wszystkim na omówieniu wyników przeprowadzonych badań empirycznych.

\section{Specyfika inwestycji gminnych}

Trwały wzrost gospodarczy nie jest możliwy bez inwestycji. Bardzo ważnym elementem kształtowania procesów rozwoju lokalnego i regionalnego jest realizacja gminnych inwestycji infrastrukturalnych, które w wielu przypadkach stanowią dźwignię tych procesów. Ich poziom i wartość są również traktowane jako wskaźnik efektywności gospodarczej i uwarunkowanie rozwoju przedsiębiorczości [Ratajczak, 1999, s. 53].

Działalność inwestycyjna gmin ma na celu tworzenie majątku trwałego, który jest podstawa produkcji i świadczenia usług niezbędnych do zaspokojenia potrzeb mieszkańców i lokalnej gospodarki. Inwestycje komunalne mogą mieć charakter: restytucyjny, modernizacyjny lub rozwojowy.

Inwestycje komunalne stanowią strategiczną sferę aktywności jednostek samorządu terytorialnego, co wiąże się zarówno ze wspomagającą rolą inwestycji w realizacji zadań bieżących, jak i ich wpływem na wzrost oraz rozwój lokalny i regionalny. JST, jako kreatorzy i realizatorzy strategii rozwoju, odpowiadają za politykę inwestycyjną, w ramach której podejmowane są decyzje dotyczące wielkości i kierunków wydatkowania publicznych środków finansowych na ten cel [Zioło, 2012, s. 213].

Planując rozwój infrastruktury komunalnej należy zwrócić uwagę na takie jej cechy, jak: służebny charakter, kapitałochłonność, niepodzielność techniczną, długowieczność, immobilność, wzajemną współzależność różnych elementów infrastrukturalnych [Ginsbert-Gebert, 1977, s. 119]. Mają one istotny wpływ na koszty realizacji zadań, a tym samym stanowią duże obciążenia dla lokalnych budżetów.

Planując inwestycje komunalne, należy mieć na uwadze, że jednostki terytorialne rozwijaja się progowo. Progi rozwoju mają różnorodny charakter: przestrzenny, strukturalny i ilościowy [Malisz, Żurkowski, 1971, s. 34]. Każdorazowe przekroczenie tych progów wymaga znacznych nakładów finansowych. Zarządzając procesami rozwoju miast i regionów, powinno się hamować rozwój w okresie przedprogowym i przyspieszać po jego przekroczeniu. Pokonywanie kolejnych progów należy umie- 
jętnie rozkładać w czasie [Sadowy, 1995, s. 92]. Przy rozbudowie infrastruktury powinno się uwzględniać przyszłe potrzeby i w miarę możliwości antycypować przyszłe zapotrzebowanie na poszczególne usługi infrastrukturalne.

Kształtowanie procesów rozwoju lokalnego wymaga koordynacji działań inwestycyjnych, szczególnie wzajemnego dopasowania poszczególnych elementów infrastruktury pod względem przestrzennym i czasowym [Ginsbert-Gebert, 1977, s. 233]. Realizacja inwestycji infrastrukturalnych powinna wyprzedzać przyszłe zapotrzebowanie, odpowiednio do przewidywanych kierunków rozwoju gospodarczego, tak aby nie prowadzić do powstania dużego progu rozwojowego, a tym samym zahamowania tempa rozwoju lokalnej gospodarki.

Planując rozwój infrastruktury, należy mieć na uwadze substytucyjność i komplementarność jej elementów. Zależności te nakazuja w sposób kompleksowy programować procesy jej rozbudowy.

Inwestycje komunalne mają charakter ciagły. Ze względu na cechy infrastruktury należy umiejętnie przeprowadzać szacunek zapotrzebowania na poszczególne rodzaje usług, tak by realizacja projektów mogła przyczyniać się do zaspokojenia potrzeb zgłaszanych przez mieszkańców i podmioty gospodarcze, a jednocześnie nie stała w sprzeczności z możliwościami finansowymi gminy. Dla uporządkowania tych procesów, wskazanym jest uchwalanie wieloletnich planów inwestycyjnych, jako programu możliwych do realizacji zadań inwestycyjnych.

Władze lokalne, podejmując decyzje inwestycyjne, tworzą tzw. montaż finansowy, budują polityki finansowania, czy też strategie finansowe, które maja za zadanie odpowiedzieć na pytanie: w jaki sposób sfinansować inwestycje? Można tu wyróżnić wiele podejść, sposobów i strategii [Filipiak, Dylewski, 2015, s. 867]. Złożoność procesu finansowania inwestycji wynika z uwarunkowań społeczno-gospodarczych i terytorialnych oraz ze specyfiki prowadzonej gospodarki i polityki finansowej. Istotne znaczenie $\mathrm{w}$ tym procesie ma zdolność do pozyskiwania dotacji unijnych.

W polityce regionalnej Unii Europejskiej na rozwój infrastruktury lokalnej przeznacza się duże kwoty środków pomocowych służących wspieraniu procesów rozwoju. Inwestycje infrastrukturalne mają charakter rozwojowy. Poprzez rozwój infrastruktury dochodzi do zwiększenia atrakcyjności i konkurencyjności danego terenu jako potencjalnego miejsca zamieszkania, wypoczynku, czy też lokalizacji podmiotów gospodarczych. Niedorozwój infrastruktury stanowi natomiast istotną barierę rozwojowa, szczególnie dla wsi i małych miast.

\section{Poziom i kierunki alokacji dotacji unijnych}

W latach 2006-2016 do budżetów gmin wpłynęło łącznie 70,4 mld zł dotacji unijnych, tj. prawie $3 / 4$ środków pomocowych $z$ funduszy strukturalnych i Funduszu Spójności trafiających do polskich samorządów. Zdecydowaną ich większość stanowiły dotacje inwestycyjne. Tak duży udział gmin w podziale środków unijnych należy tłumaczyć znacznie większym zakresem ich odpowiedzialności za usługi publiczne niż w powiatach i województwach. 
Wielkość dotacji unijnych wraz z wkładem krajowym z budżetu państwa ewidencjonowanych w dochodach gmin w latach 2006-2016 przedstawiono w tabeli 1.

TABELA 1

\section{Środki z Unii Europejskiej na finansowanie programów i projektów unijnych $\mathrm{w} \mathrm{mln} \mathrm{z} 1$}

\begin{tabular}{|l|c|c|c|c|c|c|c|c|c|c|c|c|}
\hline $\begin{array}{c}\text { Wyszczegól- } \\
\text { nienie }\end{array}$ & $\mathbf{2 0 0 6}$ & $\mathbf{2 0 0 7}$ & $\mathbf{2 0 0 8}$ & $\mathbf{2 0 0 9}$ & $\mathbf{2 0 1 0}$ & $\mathbf{2 0 1 1}$ & $\mathbf{2 0 1 2}$ & $\mathbf{2 0 1 3}$ & $\mathbf{2 0 1 4}$ & $\mathbf{2 0 1 5}$ & $\mathbf{2 0 1 6}$ & $\begin{array}{c}\text { Razem } \\
\mathbf{2 0 0 6}-2016\end{array}$ \\
\hline $\begin{array}{l}\text { Gminy + miasta } \\
\text { na prawach }\end{array}$ & 2122 & $\mathbf{3} 275$ & 2611 & $\mathbf{3} 655$ & $\mathbf{7} 496$ & 9283 & 10459 & 8630 & 9569 & 9528 & $\mathbf{3} 795$ & $\mathbf{7 0} 423$ \\
\hline \multicolumn{10}{|c|}{ w tym: } \\
\hline $\begin{array}{l}\text { Miasta na } \\
\text { prawach powiatu }\end{array}$ & 842 & 1841 & 1545 & 1778 & 2743 & 3213 & 4958 & 4560 & 5206 & 4936 & 2454 & 34074 \\
\hline Gminy ogółem & 1280 & 1434 & 1066 & 1877 & 4753 & 6070 & 5501 & 4071 & 4363 & 4592 & 1342 & 36349 \\
\hline \multicolumn{10}{|c|}{} \\
\hline Gminy miejskie & 289 & 308 & 343 & 516 & 1107 & 1233 & 990 & 722 & 719 & 644 & 338 & 7209 \\
\hline Gminy wiejskie & 597 & 611 & 352 & 746 & 2050 & 2897 & 2625 & 2047 & 2224 & 2594 & 521 & 17265 \\
\hline $\begin{array}{l}\text { Gminy } \\
\text { miejsko-wiejskie }\end{array}$ & 394 & 515 & 371 & 616 & 1596 & 1940 & 1886 & 1301 & 1420 & 1354 & 482 & 11875 \\
\hline
\end{tabular}

Źródło: opracowanie własne na podstawie danych Ministerstwa Finansów - Sprawozdania budżetowe gmin.

Dane liczbowe przedstawione w tabeli 1 niemal w całym badanym okresie wykazują tendencję wzrostową dochodów z dotacji unijnych. Zwiększyły się one z 2,12 mld zł w 2006 r. do 10,46 mld zł w 2010 r. oraz 9,52 mld zł w 2015 r., po czym w 2016 r. zanotowano bardzo duży spadek ich wysokości - do 3,8 mld zł. Główną przyczyną były opóźnienia w uruchomieniu środków z perspektywy finansowej 2014-20201.

Poszczególne lata badanego przedziału czasowego (2006-2016) cechował zróżnicowany poziom alokacji środków unijnych. Mniejsze kwoty wydatkowano w latach 2006-2009 (rocznie od 3,0\% do 5,2\% całości środków badanego okresu). Było to przede wszystkim następstwem opóźnień w uruchomieniu procedur konkursowych, w części także skutkiem kryzysu finansowego i gospodarczego. Znacznie intensywniej wykorzystywano dotacje unijne po $2010 \mathrm{r}$. W każdym kolejnym roku wydatkowano wówczas co najmniej 10\% ogólnej puli środków unijnych okresu 20062016. Najlepsze wyniki wystapiły w latach: 2014 (14,9\%) i 2013 (13,5\%) oraz 2015 $(13,3 \%)$. Znaczący spadek (do 5,4\%) zanotowano dopiero w 2016 r.

1 Do opóźnienia przyczyniły się m.in. kwestie prawne - polski parlament nie zdążył znowelizować na czas prawa zamówień publicznych, by było ono zgodne z dyrektywami UE. Rząd apelował wtedy do samorządów o wstrzymanie się z ogłaszaniem przetargów na projekty finansowane z pieniędzy UE, aby nie powodować problemów z kwalifikowalnością wydatków, a następnie możliwością refundacji środków z UE. 
W latach 2006-2015 dynamika dochodów unijnych była także zróżnicowana w poszczególnych typach gmin. Najwyższy ich przyrost zanotowano w miastach na prawach powiatu (prawie 6-krotny), niższy w gminach wiejskich (ponad 4-krotny), miejsko-wiejskich (wzrost prawie 3,5-krotny), a najniższy w miejskich (wzrost 2,2-krotny). W 2016 roku największy spadek wsparcia unijnego zanotowano w gminach wiejskich (20\% wartości 2015 roku), a mniejszy, ale także bardzo znaczacy, w miastach na prawach powiatu (50\%) i gminach miejskich $(47 \%)$.

Zdecydowanie największym beneficjentem środków unijnych były miasta na prawach powiatu. Pozyskały one łącznie 34,1 mld zł (tj. 48,4\% środków badanej grupy jednostek). Sytuacja dużych miast kształtuje się jeszcze korzystniej po uwzględnieniu dotacji unijnych pozyskiwanych bezpośrednio przez spółki komunalne. W miastach na prawach powiatów projekty, których beneficjentem była bezpośrednio spółka miejska, stanowiły około 30\% pozyskiwanych środków, podczas gdy w gminach było to zaledwie kilka procent ${ }^{2}$.

Wśród gmin największe kwoty dotacji unijnych trafily do gmin wiejskich 13,3 mld zł (24\% ogółu), a następnie miejsko-wiejskich - 11,9 mld zł (18,7\%) i miejskich $-7,2$ mld zł $(10,2 \%)$. Na podstawie wyników autorskich badań ankietowych można stwierdzić, że rocznie około $20 \%$ zadań inwestycyjnych gmin było finansowanych ze środków unijnych.

Finansowanie projektów unijnych gmin następowało za pośrednictwem 16 programów regionalnych (RPO), zarządzanych przez władze województw, a także programów krajowych, w szczególności PO Infrastruktura i Środowisko, PO Polska Cyfrowa, PO Polska Wschodnia. Dla dużych miast i dla związków komunalnych najważniejszym programem operacyjnym był POIŚ, a dla pozostałych kategorii samorządów - RPO.

Wyniki badań ankietowych wykazują dwa główne kierunki alokacji funduszy unijnych. Pierwszy to inwestycje wodociagowo-ściekowe, w tym w ostatnich latach przede wszystkim rozbudowa infrastruktury kanalizacyjnej i oczyszczania ścieków, a drugi - przedsięwzięcia budowy i modernizacji dróg oraz ciagów pieszych. Inne współfinansowane zadania to: obiekty kultury, oświaty, zdrowia, sportu i rekreacji, a także przedsięwzięcia rewitalizacji obszarów miejskich. Dotacje kierowano również na przygotowywanie nowych terenów inwestycyjnych przeznaczonych pod działalność gospodarczą lub budownictwo mieszkaniowe oraz budowę sieci informatycznych. Osobna grupa wsparcia to rozwój zasobów ludzkich, w tym: szkolenia, kursy zawodowe, staże, zajęcia w szkołach.

2 Na podstawie przeprowadzonych badań autorskich. Podobne wyniki wykazują P. Swianiewicz i J. Lukomska, Fundusze europejskie Ranking wykorzystania środków z UE w latach 2004-201, http:// www.wspolnota.org.pl/fileadmin/pliki/Andrzej_Gniadkowski/Ranking_UE/Ranking_Fundusze_ europejskie.pdf 


\section{Regionalne zróżnicowanie alokacji dotacji unijnych}

Istotnym problemem polskiej gospodarki są duże regionalne dysproporcje rozwojowe, widoczne zwłaszcza między regionami Polski Zachodniej i Wschodniej. W ostatnich dekadach największa luka w tym zakresie występowała w gminach pięciu województw wschodnich, tj.: lubelskim, podkarpackim, podlaskim, świętokrzyskim i warmińsko-mazurskim³ ${ }^{3}$ Przejawiało się to głównie w nienowoczesnej strukturze gospodarki, małej atrakcyjności inwestycyjnej oraz nasilonych niekorzystnych przemianach demograficznych. Dla niwelowania występujących różnic, a tym samym dysproporcji regionalnych, cześć dotacji unijnych ${ }^{4}$ została skierowana do gmin zlokalizowanych we wschodniej części kraju.

W tabeli 2 w układzie województw zestawiono wielkość środków z Unii Europejskiej kierowanych na finansowanie programów i projektów unijnych.

Analiza danych liczbowych wykazuje znaczące dysproporcje przestrzenne alokacji środków unijnych. W latach 2006-2016 największe wartości dotacji unijnych wpłynęły do gmin województw: mazowieckiego (11,5 mld zł, co stanowiło 16,4\% ogółu środków), śląskiego (9,7 mld zł, 13,8\%), pomorskiego (5,97 $\mathrm{mln}$ zł, 8,5\%) i małopolskiego (5,1 mld zl, 7,3\%); a najniższe do: opolskiego (1,2 mld zł, 1,6\%), lubuskiego (1,6 mld zł, 2,3\%), świętokrzyskiego (2,77 mld zł, 3,9\%) i podlaskiego (2,8 mld zł, 4,0\%).

Wśród gmin największa alokacja okresu 2006-2016 przypadła na jednostki zlokalizowane w województwach: mazowieckim (12,2\% ogółu dotacji unijnych), małopolskim $(10,0 \%)$, śląskim $(9,4 \%)$, lubelskim $(81 \%)$ i podkarpackim $(7,9 \%)$; a najniższa w: opolskim (2,5\%), lubuskim $(3,3 \%)$ i podlaskim $(3,5 \%)$.

W grupie miast na prawach powiatu największe środki unijne wykorzystano w województwach: mazowieckim (18,6\% ogółu), pomorskim (11,3\%), dolnośląskim $(7,2 \%)$, łódzkim $(7,2 \%)$; a najmniejsze w opolskim $(0,7 \%)$, lubuskim $(1,2 \%)$, świętokrzyskim $(2,2 \%)$ i zachodniopomorskim (3,4\%).

Podane powyżej wartości wyraźnie uwidaczniają współzależność wielkości pozyskiwanych dotacji unijnych z liczbą ludności oraz poziomem rozwoju społeczno-gospodarczego gmin. Pewne znaczenie ma także ich powierzchnia. Zależności te widoczne są zarówno w miastach jak i w gminach, a potwierdzają je wartości dotacji alokowanych w takich jednostkach następujących województw: mazowieckie, śląskie, małopolskie, a z drugiej strony: opolskie, lubuskie i świętokrzyskie.

Analiza zróżnicowania regionalnego alokacji środków unijnych wg typów gmin we wszystkich kategoriach wykazuje bardzo silną pozycję województwa mazowieckiego, jako drugie należy wskazać województwo śląskie. Poza dwoma wymienionymi, wysokie środki uzyskały gminy w województwach: pomorskim, dolnośląskim, łódzkim. Z kolei województwa małopolskie i lubelskie notowały dobre wyniki w gminach wiejskich i miejskich.

Obszar tych województw zajmuje 31,6\% powierzchni.

4 W tym specjalne Programy Operacyjne - w latach 2007-2013 PO „Rozwój Polski Wschodniej”, a w perspektywie lat 2014-2020 - PO „Polska Wschodnia”. 
TABELA 2

Środki z Unii Europejskiej na finansowanie programów i projektów unijnych w mln zł - wartości zsumowane dla okresu 2006-2016

- wg typów gmin i województw w mln zł

\begin{tabular}{|c|c|c|c|c|c|c|}
\hline Wyszczególnienie & $\begin{array}{c}\text { Gminy } \\
\text { (z miastami } \\
\text { na prawach } \\
\text { powiatu } \\
\text { łącznie) }\end{array}$ & $\begin{array}{c}\text { Miasta } \\
\text { na prawach } \\
\text { powiatu }\end{array}$ & $\begin{array}{c}\text { Gminy } \\
\text { ogółem }\end{array}$ & $\begin{array}{c}\text { Gminy } \\
\text { miejskie }\end{array}$ & $\begin{array}{l}\text { Gminy } \\
\text { miejsko- } \\
\text { wiejskie }\end{array}$ & $\begin{array}{c}\text { Gminy } \\
\text { wiejskie }\end{array}$ \\
\hline Polska & 70422,9 & 34074,2 & 36348,7 & 7208,7 & 11875,0 & 17265,0 \\
\hline dolnośląskie & 4987,7 & 2465,8 & 2521,9 & 850,4 & 880,4 & 791,2 \\
\hline kujawsko-pomorskie & 3731,8 & 2097,4 & 1634,4 & 322,3 & 564,9 & 747,2 \\
\hline lubelskie & 4618,6 & 1661,6 & 2957,0 & 680,2 & 483,3 & 1793,5 \\
\hline lubuskie & 1606,0 & 415,5 & 1190,5 & 210,8 & 621,3 & 358,5 \\
\hline łódzkie & 4984,7 & 2451,5 & 2533,2 & 676,3 & 741,1 & 1115,8 \\
\hline małopolskie & 5119,3 & 1468,2 & 3651,2 & 282,3 & 1611,5 & 1757,3 \\
\hline mazowieckie & 11546,6 & 7106,0 & 4440,6 & 929,3 & 1228,3 & 2283,1 \\
\hline opolskie & 1151,6 & 239,4 & 912,2 & 94,8 & 512,5 & 304,9 \\
\hline podkarpackie & 4538,6 & 1671,3 & 2867,3 & 497,2 & 752,2 & 1617,9 \\
\hline podlaskie & 2804,6 & 1539,6 & 1265,0 & 235,0 & 318,0 & 712,0 \\
\hline pomorskie & 5967,2 & 3847,0 & 2120,2 & 679,1 & 376,5 & 1064,6 \\
\hline śląskie & 9737,8 & 6340,6 & 3397,2 & 1235,5 & 589,7 & 1571,9 \\
\hline świętokrzyskie & 2767,6 & 745,1 & 2022,5 & 234,8 & 608,9 & 1178,9 \\
\hline warmińsko-mazurskie & 3149,5 & 1280,8 & 1868,7 & 518,6 & 700,0 & 650,2 \\
\hline wielkopolskie & 4201,3 & 2052,4 & 2148,8 & 200,7 & 1080,8 & 867,3 \\
\hline zachodniopomorskie & 2826,2 & 1157,9 & 1668,3 & 411,8 & 805,9 & 450,7 \\
\hline
\end{tabular}

Źródło: opracowanie własne na podstawie [Ministerstwo Finansów, Sprawozdania budżetowe gmin].

Skutecznością wykazały się także gminy województw wschodnich, przede wszystkim: lubelskiego, podkarpackiego i świętokrzyskiego. Najmniej środków unijnych pozyskiwały jednostki zlokalizowane w województwach: opolskim i lubuskim. Niskie wartości notowano także w gminach miejskich i miastach na prawach powiatu województwa świętokrzyskiego oraz miejskich i wiejskich województwa podlaskiego.

Analiza rozkładu przestrzennego pomocy unijnej w ujęciu poszczególnych jednostek terytorialnych, wykazuje pogłębiające się różnice pomiędzy gminami bogatymi a biednymi. Potwierdzają to kwoty środków, jakie otrzymują stolice regionów oraz gminy o wysokim poziomie rozwoju i wysokim własnym potencjale finansowym. Tak więc istniejące w polityce regionalnej UE preferencje wsparcia obszarów słabiej rozwiniętych mają zastosowania w alokacji dotacji pomiędzy województwa. 
Nie zapobiegają natomiast temu, że większość funduszy pozyskuja gminy bardziej zasobne finansowo.

Przyczyny takiego zróżnicowania wydają się oczywiste. Jednostki o wyższej bazie ekonomicznej i silnym potencjale finansowym są w stanie zapewnić wymagany poziom wkładu własnego w realizacji projektów. Mają także większą zdolność do zaciagania zobowiązań dłużnych. Dodatkowo zatrudniają wykwalifikowanych pracowników i zewnętrznych konsultantów, potrafiących dobrze przygotować i realizować projekty.

\section{Udział dotacji unijnych w finansowaniu wydatków inwestycyjnych gmin}

Oprócz analizy wsparcia unijnego w ujęciu wartościowym, warto zwrócić uwagę na znaczenie dotacji z budżetu Unii Europejskiej kierowanych na inwestycje gmin. Można to ocenić na podstawie wskaźnika udziału tychże środków w wydatkach inwestycyjnych. Wyniki obliczeń tego wskaźnika dla gmin zestawione na poziomie poszczególnych województw przedstawiono w tabeli 3.

TABELA 3

Udział środków z budżetu Unii Europejskiej przekazanych w formie dotacji na inwestycje gmin w wydatkach majątkowych ich budżetów zsumowane w układzie województw w latach 2006-2016

\begin{tabular}{|l|c|c|c|c|c|c|c|c|c|c|c|}
\hline Wyszczególnienie & $\mathbf{2 0 0 6}$ & $\mathbf{2 0 0 7}$ & $\mathbf{2 0 0 8}$ & $\mathbf{2 0 0 9}$ & $\mathbf{2 0 1 0}$ & $\mathbf{2 0 1 1}$ & $\mathbf{2 0 1 2}$ & $\mathbf{2 0 1 3}$ & $\mathbf{2 0 1 4}$ & $\mathbf{2 0 1 5}$ & $\mathbf{2 0 1 6}$ \\
\hline Polska & $11,4 \%$ & $16,2 \%$ & $11,0 \%$ & $13,1 \%$ & $23,1 \%$ & $30,7 \%$ & $40,3 \%$ & $35,5 \%$ & $33,3 \%$ & $36,1 \%$ & $20,7 \%$ \\
\hline dolnoślaskie & $11,2 \%$ & $21,9 \%$ & $8,3 \%$ & $9,1 \%$ & $21,2 \%$ & $31,6 \%$ & $36,1 \%$ & $31,9 \%$ & $23,6 \%$ & $24,2 \%$ & $17,3 \%$ \\
\hline $\begin{array}{l}\text { kujawsko- } \\
\text {-pomorskie }\end{array}$ & $8,0 \%$ & $22,4 \%$ & $10,4 \%$ & $10,0 \%$ & $21,4 \%$ & $25,9 \%$ & $35,9 \%$ & $34,0 \%$ & $30,1 \%$ & $49,1 \%$ & $17,6 \%$ \\
\hline lubelskie & $15,4 \%$ & $21,4 \%$ & $11,2 \%$ & $10,3 \%$ & $30,7 \%$ & $40,7 \%$ & $55,9 \%$ & $55,3 \%$ & $41,1 \%$ & $43,3 \%$ & $20,5 \%$ \\
\hline lubuskie & $13,4 \%$ & $29,1 \%$ & $10,9 \%$ & $22,4 \%$ & $26,3 \%$ & $33,8 \%$ & $45,6 \%$ & $42,1 \%$ & $33,9 \%$ & $34,1 \%$ & $12,7 \%$ \\
\hline lódzkie & $15,9 \%$ & $15,0 \%$ & $13,5 \%$ & $26,9 \%$ & $33,5 \%$ & $28,7 \%$ & $34,6 \%$ & $37,4 \%$ & $26,6 \%$ & $37,8 \%$ & $26,8 \%$ \\
\hline małopolskie & $7,8 \%$ & $8,2 \%$ & $5,7 \%$ & $12,2 \%$ & $27,7 \%$ & $32,4 \%$ & $33,2 \%$ & $29,6 \%$ & $32,4 \%$ & $33,8 \%$ & $20,1 \%$ \\
\hline mazowieckie & $8,7 \%$ & $9,0 \%$ & $10,9 \%$ & $9,6 \%$ & $18,6 \%$ & $33,0 \%$ & $46,6 \%$ & $32,6 \%$ & $39,4 \%$ & $40,7 \%$ & $29,9 \%$ \\
\hline opolskie & $10,7 \%$ & $14,1 \%$ & $8,1 \%$ & $14,3 \%$ & $25,3 \%$ & $31,8 \%$ & $36,3 \%$ & $24,8 \%$ & $28,5 \%$ & $26,6 \%$ & $13,0 \%$ \\
\hline podkarpackie & $16,9 \%$ & $20,4 \%$ & $16,3 \%$ & $19,2 \%$ & $34,6 \%$ & $41,3 \%$ & $48,0 \%$ & $49,7 \%$ & $44,6 \%$ & $37,7 \%$ & $19,6 \%$ \\
\hline podlaskie & $16,7 \%$ & $18,8 \%$ & $11,0 \%$ & $28,9 \%$ & $33,3 \%$ & $40,6 \%$ & $44,5 \%$ & $36,6 \%$ & $41,2 \%$ & $34,0 \%$ & $22,3 \%$ \\
\hline pomorskie & $13,1 \%$ & $24,1 \%$ & $11,5 \%$ & $7,8 \%$ & $17,5 \%$ & $26,3 \%$ & $57,5 \%$ & $52,3 \%$ & $38,0 \%$ & $41,4 \%$ & $26,3 \%$ \\
\hline ślaskie & $13,5 \%$ & $21,5 \%$ & $21,5 \%$ & $18,8 \%$ & $28,7 \%$ & $34,6 \%$ & $40,2 \%$ & $34,1 \%$ & $35,7 \%$ & $34,2 \%$ & $26,5 \%$ \\
\hline świętokrzyskie & $22,5 \%$ & $14,9 \%$ & $6,5 \%$ & $21,0 \%$ & $34,5 \%$ & $43,7 \%$ & $44,6 \%$ & $47,9 \%$ & $42,4 \%$ & $40,3 \%$ & $22,3 \%$ \\
\hline $\begin{array}{l}\text { warmińsko- } \\
\text { mazurskie }\end{array}$ & $14,7 \%$ & $28,8 \%$ & $14,9 \%$ & $15,3 \%$ & $29,4 \%$ & $45,6 \%$ & $49,3 \%$ & $48,8 \%$ & $43,2 \%$ & $43,6 \%$ & $26,0 \%$ \\
\hline wielkopolskie & $10,5 \%$ & $19,1 \%$ & $7,6 \%$ & $6,5 \%$ & $10,6 \%$ & $19,2 \%$ & $35,5 \%$ & $26,6 \%$ & $20,9 \%$ & $37,5 \%$ & $7,3 \%$ \\
\hline $\begin{array}{l}\text { zachodnio- } \\
\text { pomorskie }\end{array}$ & $9,4 \%$ & $20,4 \%$ & $11,5 \%$ & $6,8 \%$ & $13,2 \%$ & $22,9 \%$ & $33,6 \%$ & $33,3 \%$ & $33,4 \%$ & $33,7 \%$ & $28,7 \%$ \\
\hline
\end{tabular}

Źródło: opracowanie własne na podstawie [Ministerstwo Finansów, Sprawozdania budżetowe gmin]. 
Na podstawie uzyskanych wyników obliczeń należy stwierdzić, że udział środków unijnych w wydatkach inwestycyjnych gmin wykazywał w skali kraju i poszczególnych województw dużą zmienność w czasie. Najniższy jego poziom cechował lata $2008(11,0 \%), 2006(11,4 \%)$ i 2009 (13,1\%), a najwyższy: 2012 (40,3\%), $2015(36,1 \%)$ i $2013(35,5 \%)$.

Tak w skali kraju, jak i większości województw, najwyższe wartości wskaźnika notowano w latach 2010-2015. Szczególnie intensywny był okres 2011-2013, gdy w niektórych regionach jego przyrost przekroczył 50\%. Taka sytuacja miała miejsce w 2012 r. w województwach lubelskim (54,8\%) oraz pomorskim (55,3\%). Uzyskana wysoka wartość wskaźnika oznaczała, że na inwestycje na poziomie lokalnym wydatkowano więcej środków unijnych niż ze wszystkich innych źródeł łącznie. Poprawa wyników po 2010 r. wynikała z uruchomienia dużego wolumenu środków w ramach konkursów współfinansowanych z RPO i pozostałych programów operacyjnych.

Analizując znaczenie dotacji unijnych w finansowaniu inwestycji gmin w poszczególnych województwach, należy zwrócić uwagę na występujące tu istotne różnice regionalne. Średni roczny udział analizowanego wskaźnika liczonego dla okresu 2006-2016 wyniósł w skali kraju 24,7\%. Najwyższy jego poziom cechował gminy województw: warmińsko-mazurskiego (32,7\%), podkarpackiego (31,7\%), lubelskiego $(31,4 \%)$, świętokrzyskiego $(30,9 \%)$ i podlaskiego $(29,8 \%)$, a najniższy: wielkopolskiego $(18,3 \%)$, opolskiego $(21,2 \%)$, dolnośląskiego $(21,5 \%)$ i małopolskiego $(22,1 \%)$.

Znaczący wzrost znaczenia dotacji unijnych w finansowaniu inwestycji gmin zanotowano w województwach o niższym potencjale dochodowym i niskiej wartości wydatków inwestycyjnych: podlaskim, łódzkim, świętokrzyskim i lubuskim. Należy to uznać za ważne zjawisko ekonomiczne - dotacje unijne miały pozytywny wpływ na procesy stymulowania rozwoju społeczno-gospodarczego. Nastąpiło to przez zwiększenie potencjału inwestycyjnego i faktyczne rozszerzenie wolumenu inwestycji, co miało istotne znaczenie dla warunków życia ludności i funkcjonowania lokalnej gospodarki.

\section{Współzależność dotacji unijnych i wydatków inwestycyjnych}

Podejmując próbę pogłębionej analizy systemu finansowania inwestycji gmin w warunkach członkostwa Polski w UE, istotnym wydaje się określenie związków między rozmiarami dostępnych dla nich dotacji unijnych z podstawowymi kategoriami ich gospodarki budżetowej, związanymi bezpośrednio z działalnością inwestycyjna. Dla wykazania związków prostoliniowych badanych zmiennych wykorzystano współczynnik korelacji Pearsona przeliczonych per capita wielkości uzyskanych przez gminy środków UE z również przeliczonymi per capita wielkościami wydatków inwestycyjnych w latach 2006-2016. Powyższe wielkości wyliczono dla agregatów wojewódzkich, co sprawia, że prezentowany poziom współczynników korelacji wskazuje tu, ze względu na małą liczebność próby, jedynie mniejszą lub większą możliwość występowania związków między analizowanymi kategoriami. 
Obliczona wartość współczynnika korelacji Pearsona dla wszystkich gmin w Polsce wykazuje słabą współzależność badanych zmiennych - na poziomie 0,37. Wśród typów gmin najsilniejszy związek zanotowano w gminach miejsko-wiejskich $(0,53)$, niższy w wiejskich $(0,48)$, a najniższy w miejskich $(0,27)^{5}$. Tak więc w latach 2006-2016 notowano dość słabe związki między względnym poziomem dotacji unijnych a względnymi wydatkami inwestycyjnymi gmin ogółem (w ujęciu per capita). Jedynie w gminach miejsko-wiejskich siłę tego związku można uznać za umiarkowana.

Badanie zależności pomiędzy wielkością dotacji unijnych a wydatkami inwestycyjnymi gmin przeprowadzono także dla wartości zagregowanych na poziomie województw. Wyniki obliczeń przedstawiono w tabeli 4.

TABELA 4

Wielkość dotacji UE a rozmiary wydatków inwestycyjnych w przeliczeniu na 1 mieszkańca gmin - związki korelacyjne (liczone dla wartości zsumowanych na poziomie województw - lata 2006-2016)

\begin{tabular}{|l|l|l|l|l|l|l|l|}
\hline mazowieckie & $-0,09$ & lubuskie & 0,29 & podlaskie & 0,56 & $\begin{array}{l}\text { warmińsko- } \\
\text { mazurskie }\end{array}$ & 0,66 \\
\hline $\begin{array}{l}\text { zachodnio- } \\
\text { pomorskie }\end{array}$ & 0,14 & $\begin{array}{l}\text { kujawsko- } \\
\text { pomorskie }\end{array}$ & 0,38 & dolnośląskie & 0,59 & lubelskie & 0,66 \\
\hline wielkopolskie & 0,24 & śląskie & 0,47 & pomorskie & 0,59 & podkarpackie & 0,74 \\
\hline łódzkie & 0,28 & małopolskie & 0,48 & opolskie & 0,64 & świętokrzyskie & 0,80 \\
\hline
\end{tabular}

Źródło: obliczenia własne autora.

Wyraźniejszy poziom współzależności badanych zjawisk dostrzec można jedynie w przypadku gmin województw: podlaskiego $(+0,88)$, świętokrzyskiego $(+0,82)$ i podkarpackiego $(+0,79)$. W dalszej kolejności wymienić można: śląskie $(+0,58)$, lubuskie $(+0,56)$, kujawsko-pomorskie $(+0,55)$, opolskie $(+0,46)$ i małopolskie $(+0,45)$. Dodatnie zwiazki korelacyjne o wartości poniżej średniej krajowej zanotowano w: zachodniopomorskim $(+0,31)$ i dolnośląskim $(+0,08)$, a w województwach: wielkopolskim i mazowieckim korelacja była ujemna (o wartości -0,18 i-0,15).

W gminach miejskich wysoką współzależność między względnym poziomem dotacji unijnych a względnymi wydatkami inwestycyjnymi zanotowano jedynie w gminach miejskich województw: podlaskiego $(0,93)$, podkarpackiego $(0,84)$, a nieco niższa - łódzkiego $(0,78)$. Ujemne związki wykazały gminy województw: dolnośląskiego $(-0,2)$, wielkopolskiego $(-0,13)$ oraz mazowieckiego $(-0,05)$, a praktycznie brak związku cechował województwa: małopolskie i opolskie. Ogółem można stwierdzić, że wyniki obliczeń przeprowadzone dla gmin miejskich w więk-

5 Ze względu na występującą w większości województw niewielką liczbę miast na prawach powiatu zrezygnowano z liczenia związków korelacyjnych dla tej grupy. 
szości województw wykazują słabe związki korelacyjne pomiędzy wielkością dotacji unijnych a poziomem wydatków inwestycyjnych (w przeliczeniu na mieszkańca).

Dużo mniejsze różnice regionalne cechowały gminy miejsko-wiejskie. Najwyższą współzależność między względnym poziomem dotacji unijnych a względnymi wydatkami majątkowymi dostrzec można w gminach województw: świętokrzyskiego $(0,83)$, lubelskiego $(0,79)$, łódzkiego $(0,78)$, kujawsko-pomorskiego $(0,74)$, małopolskiego i warmińsko-mazurskiego $(0,73)$. Korelację ujemną wykazało województwo mazowieckie $(-0,22)$, a słabe związki cechowały jednostki zlokalizowane w: wielkopolskim i zachodniopomorskim $(0,26)$.

Wśród gmin wiejskich wyraźniejszy poziom współzależności badanych zjawisk wystąpił jedynie w województwach: świętokrzyskim $(0,80)$, podkarpackim $(0,74)$, lubelskim $(0,66)$ i warmińsko-mazurskim $(0,66)$. Ujemne związki cechowały jednostki województwa mazowieckiego $(-0,09)$, a słaba siłę korelacji zanotowano w województwach: zachodniopomorskim $(0,14)$, wielkopolskim $(0,24)$, łódzkim $(0,28)$ i lubuskim $(0,29)$.

Dla wyjaśnienia opisanej powyżej siły związków korelacyjnych warto wskazać kilka uwarunkowań funkcjonowania jednostek terytorialnych w Polsce. Pierwsze to zróżnicowanie rozwoju społeczno-gospodarczego w układzie regionalnym i wynikające z tego konsekwencje budżetowe. Należy tu przede wszystkim zwrócić uwagę na niższy poziom rozwoju, a jednocześnie wysoki zakres potrzeb w województwach tzw. ściany wschodniej. Mają one najniższy poziom wskaźnika PKB na mieszkańca, co, zgodnie z zasadami polityki regionalnej, upoważnia je do pozyskiwania wsparcia unijnego kierowanego do regionów zacofanych. Dzięki umiejętnej alokacji środków unijnych województwa te należały w ostatnich latach do najintensywniej rozwijających się obszarów kraju. Potwierdzają to zarówno omawiane wskaźniki udziału środków z budżetu Unii Europejskiej przekazanych w formie dotacji na inwestycje, jak i wskaźniki korelacji obliczone dla województw: podlaskiego, świętokrzyskiego, podkarpackiego, lubelskiego, warmińsko-mazurskiego.

O ile problemy województw ,ściany wschodniej” są powszechnie znane i prawidłowo identyfikowane, to autorskie badania międzyregionalnych zróżnicowań rozwoju oraz sytuacji finansowej gmin nakazuja zwrócić uwagę na narastające w czasie problemy przygranicznych województw zachodnich. Zlokalizowane na ich obszarze gminy cechowała stosunkowo niska współzależność badanych zmiennych korelacyjnych oraz udziału dotacji unijnych w wydatkach budżetowych. Wydaje się, że w dużym stopniu jest to następstwem lokalnych i regionalnych uwarunkowań funkcjonalno-przestrzennych. Sieć osadnicza tych województw jest stosunkowo gęsta, z dość dużą liczbą małych i średnich miast. Obszary te podlegają także niekorzystnym zmianom demograficznym, w szczególności należy wskazać na postępujące wyraźnie zmniejszanie się osób czynnych zawodowo.

Mając powyższe na uwadze, wydaje się, że programy wsparcia, jak najszybciej powinny objać jednostki terytorialne zlokalizowane w zachodniej części kraju w województwach: zachodniopomorskim, wielkopolskim, lubuskim, opolskim i dolnośląskim. Warto tu przywołać badania A. Gałązki, w których zwraca on uwagę na ilościowe i jakościowe zmiany potencjałów społeczno-gospodarczych w różnych 
skalach przestrzennych [Gałązka, 2013, s. 312] oraz występujące lokalne i subregionalne koncentracje ludności, szczególnie niekorzystne dla degresywnych aglomeracji przemysłowych, a także dla wielu obszarów peryferyjnych.

Wskazane powyżej uwarunkowania funkcjonalno-przestrzenne mają wpływ na sytuację finansowa gmin, w szczególności małych i średnich miast. W wielu z nich notowana jest nadmiernie wysoka dynamika wydatków bieżących. Wskutek wielu czynników obniża się zdolność do zaciagania nowych zobowiązań dłużnych, jak i możliwość zapewnienia odpowiednio wysokiego wkładu własnego w finansowaniu projektów unijnych. W rezultacie dochodzi do obniżenia ich potencjału rozwojowego. Tymczasem gminy nadal oczekuja dofinansowania unijnego na poziomie 60-70\% kosztów realizacji podstawowych inwestycji, tj. w zakresie gospodarki wodociagowo-ściekowej czy też dróg. W takiej sytuacji konieczne jest racjonalne kształtowanie polityki wsparcia, zwłaszcza w stosunku do małych i średnich miast. Aby można było mówić o ożywieniu procesów rozwoju tych jednostek, niezbędnym wydaje się przygotowanie wyspecjalizowanych programów, wspomagających niwelowanie istniejaccych barier funkcjonalno-przestrzennych.

Przeprowadzone badanie wykazało specyficzność gmin województwa mazowieckiego. We wszystkich kategoriach gmin zanotowano w nim ujemną korelację pomiędzy wielkością środków unijnych a wydatkami inwestycyjnymi. W części tłumaczyć to można wewnętrzną strukturą regionu. Mazowsze jest bardzo zróżnicowane pod względem rozwoju społeczno-gospodarczego. Bardzo duży wpływ na wyniki województwa ma Warszawa i zlokalizowane wokół niej gminy aglomeracyjne. Jedna z przyczyn braku współzależności badanych zmiennych jest koncentracja alokacji dotacji unijnych w jednostkach o wysokim poziomie budżetu, realizujących także szeroki zakres zadań inwestycyjnych. W takiej sytuacji realizacja projektów nie jest tak silnie uzależniona od pozyskania dotacji unijnych. Druga przyczyna to niski własny potencjał inwestycyjny wielu małych gmin o niższym poziomie rozwoju, ograniczający możliwość zapewnienia wkładu własnego na realizację projektów. Gminy te, mimo dużych potrzeb inwestycyjnych, z podanych powyżej przyczyn mają ograniczone możliwości wnioskowania o dofinansowanie unijne.

Innym istotnym problemem wielu gmin jest rozdrobnienie wiejskiej sieci osadniczej. O skali tego zjawiska świadczy fakt, że miejscowości liczące do 200 mieszkańców stanowia prawie 50\% ogółu tych jednostek. Najbardziej rozdrobniona wiejska sieć osadnicza występuje w północno-wschodniej i centralnej Polsce. Uwarunkowanie to jest czynnikiem ograniczającym możliwość realizacji wielu projektów inwestycyjnych o charakterze liniowym. W takiej sytuacji, mimo istniejących potrzeb inwestycyjnych tak z przyczyn finansowych (niski potencjał własny, wysokie koszty realizacji inwestycji), jak i technicznych (prowadzenie inwestycji na dużych odcinkach pozbawionych zabudowy) występuje ograniczona możliwość wnioskowania o dofinansowanie unijne przez jednostki zlokalizowane na typowych obszarach wiejskich.

Kończąc tę część rozważań należy zwrócić uwagę, że ze względu na bardzo wysoki poziom kapitałochłonności i długi okres realizacji inwestycji infrastrukturalnych, pozyskanie funduszy na ich finansowanie nie jest łatwym przedsięwzięciem. 
Wymagane jest tu nie tylko precyzyjne przygotowanie projektów, ale również spełnienie warunków w zakresie racjonalności kosztów realizacji i późniejszego utrzymania zrealizowanych inwestycji. Poważnym zagrożeniem dla sprawnej absorpcji środków pomocowych UE jako instrumentów finansowania inwestycji może okazać się „niewydolność” finansowa samorządu terytorialnego [Poniatowicz, 2014, s. 186]. Dodatkowo system zasilania samorządów w środki finansowe wydaje się być nieadekwatny do przypisanych jednostkom zadań, co zmusza je do poszukiwania zewnętrznych źródeł finansowania działalności, zwłaszcza inwestycyjnej, w tym środków pomocy zagranicznej pochodzących, z Unii Europejskiej [Wyszkowska, 2011, s. 309].

\section{Podsumowanie}

Dotychczasowe doświadczenia alokacji funduszy unijnych w Polsce wykazuja, że wobec realnego ryzyka ograniczania poziomu dochodów własnych samorządu terytorialnego, środki unijne powinny mieć istotny pozytywny wpływ na rozwój regionów i lokalnych jednostek samorządowych, zarówno w wymiarze finansów publicznych, jak też pośrednio wzmacnianiu koniunktury gospodarczej.

Na podstawie przeprowadzonych analiz i uzyskanych wyników obliczeń można dokonać następujących podsumowań:

- analiza występowania i siły związków korelacyjnych dla Polski ogółem wykazuje dość słabe związki pomiędzy względnym poziomem dotacji unijnych a względnymi wydatkami inwestycyjnymi gmin (w ujęciu per capita);

- obliczenia dla poszczególnych typów gmin najsilniejsze związki korelacyjne wykazują w gminach miejsko-wiejskich, nieco niższe w wiejskich, a o połowę niższe w gminach miejskich;

- w miastach największa współzależność badanych zmiennych występuje w województwach: podlaskim, podkarpackim, łódzkim, świętokrzyskim, lubelskim, warmińsko-mazurskim;

- $\quad$ w gminach zlokalizowanych na obszarach wiejskich najsilniejsze związki korelacyjne występuja w województwach: podlaskim, świętokrzyskim, podkarpackim, lubelskim, warmińsko-mazurskim;

- $\quad$ województwem, które we wszystkich typach gmin wykazuje ujemne zwiazki korelacyjne, jest województwo mazowieckie;

- określoną grupe problemową tworzą województwa: zachodniopomorskie, wielkopolskie, dolnośląskie, opolskie i małopolskie. Regiony te cechuje stosunkowo niska współzależność badanych zmiennych korelacyjnych;

- średni poziom związków korelacyjnych cechował takie województwa, jak: śląskie, pomorskie, częściowo lubuskie i opolskie. Stanowią one znacznie mniej jednorodna grupę niż analizowane wcześniej.

Istotnymi problemami w pozyskiwaniu środków z Unii Europejskiej przez gminy, wskazywanymi przez nie w badaniu ankietowym, sa:

- $\quad$ brak środków budżetowych na sfinansowanie wkładu własnego, wynikający ze zbyt niskiego potencjału finansowego; 
- $\quad$ skomplikowane procedury aplikowania o środki unijne, w tym konieczność składania wraz z wnioskiem o dofinansowanie dużej liczby załączników;

- $\quad$ zbyt długie oczekiwanie na refundację wydatków poniesionych na realizację inwestycji finansowanych przy udziale środków unijnych, wymusza zadłużanie się na dłuższy okres i może prowadzić do zachwiania płynności finansowej;

- część badanych jednostek jako istotną barierę wskazywała również wyłączenie wielu istotnych zadań lokalnych z dofinansowania dotacjami UE.

\section{Literatura}

Filipiak B., Dylewski M., 2015, Driatalność inwestycyjna jednostek samorzadu terytorialnego w latach 2008-2013, Zeszyty Naukowe Uniwersytetu Szczecińskiego, nr 854, „Finanse, Rynki Finansowe, Ubezpieczenia", nr 73.

Gałązka A., 2013, Procesy spotecžno-gospodarcze na poziomie lokalnym. Zróżnicowania i dtugookresowe trendy zmian, Oficyna Wydawnicza SGH, Warszawa.

Ginsbert-Gebert A., 1977, Zarys polityki komunalnej, Oficyna Wydawnicza SGPiS, Warszawa.

Malisz B., Żurkowski J., 1971, Metoda analisy progowej, PWN, Warszawa.

Ministerstwo Finansów, Sprawozdania budżetowe, https://www.mf.gov.pl/ministerstwo-finansow/dzialalnosc/finanse-publiczne/budzety-jednostek-samorzaduterytorialnego/sprawozdania-budżetowe.

Poniatowicz M., 2014, Uwarunkowania ak.tywności inwestycyjnej samorzadu terytorialnego w Polsce w nowej perspektywie finansowej UE 2014-2020, Zeszyty Naukowe Uniwersytetu Szczecińskiego, „Ekonomiczne Problemy Usług”, nr 115.

Ratajczak M., 1999, Infrastruktura w gospodarce rynkowej, Wydawnictwo AE, Poznań.

Sadowy M., 1995, Elementy teorii i polityki infrastruktury, [w:] Gospodarka Samorzadu terytorialnego, c₹: II, Oficyna Wydawnicza SGH, Warszawa.

Swianiewicz P. i tukomska J., Fundusze europejskie Ranking wykoraystania środkón z UE w latach 2004-201, http://www.wspolnota.org.pl/fileadmin/pliki/Andrzej_ Gniadkowski/Ranking_UE/Ranking_Fundusze_europejskie.pdf.

Wyszkowska D., 2011, Efektywność mykoraystania fundusミy pomoconych Unii Europejskiej przez, jednostki samorzadu terytorialnego, Zeszyty Naukowe Uniwersytetu Szczecińskiego, „Finanse, Rynki Finansowe, Ubezpieczenia”, nr 687.

Zioło M., 2012, Finansowanie inwestygi komunalnych przę banki, „Annales Universitatis Mariae Curie-Skłodowska, Lublin - Polonia”, vol. XLVI, 4 sectio H. 